\title{
Current progress toward vaccines against Toxoplasma gondii
}

\author{
This article was published in the following Dove Press journal: \\ Vaccine: Development and Therapy \\ 16 April 2014 \\ Number of times this article has been viewed
}

\author{
João Luis Garcia' \\ Elisabeth A Innes ${ }^{2}$ \\ Frank Katzer ${ }^{2}$ \\ 'Department of Preventative \\ Veterinary Medicine, Center of \\ Agricultural Science, State University \\ of Londrina, Parana, Brazil; ${ }^{2}$ Moredun \\ Research Institute, Pentlands Science \\ Park, Edinburgh, Scotland
}

\begin{abstract}
Toxoplasma gondii is an intracellular protozoan parasite that can infect many warm-blooded animal species and humans. Despite substantial knowledge of the biology, epidemiology, and host-pathogen interactions of $T$. gondii, there are still very few effective control strategies to prevent oocyst shedding in cats, tissue cysts in livestock for consumption, and infection and disease in humans. This article reviews current progress and targets for vaccination against $T$. gondii.
\end{abstract}

Keywords: toxoplasmosis, vaccination, livestock animals, cats, immune response, organelles

\section{Introduction}

Toxoplasma gondii is a protozoan parasite with a worldwide distribution, ${ }^{1}$ and may be found in animals from the arctic, ${ }^{2}$ rain forest, ${ }^{3}$ and arid zones, ${ }^{4}$ and even in marine mammals. ${ }^{5} T$. gondii normally causes a subclinical infection in most animal species; however, a primary infection during pregnancy can cause fetal pathology, as well as abortion in humans and some animal species. ${ }^{6,7}$ When the human fetus is infected, it may present with hydrocephalus, chorioretinitis, deafness, and impaired mental development. ${ }^{8}$ The incidence of congenital toxoplasmosis in humans is highly variable across different countries/regions. ${ }^{9}$ The recorded incidence is usually lower in Europe and North America (six cases per 1,000 live births), ${ }^{10,11}$ when compared with Brazil, where cases range from 0 to 77 per 1,000 live births depending on the level of poverty in the region studied. ${ }^{7}$ A study in Brazil reported detection of parasitemia and isolation of $T$. gondii from peripheral blood in $15.2 \%$ of children with congenital toxoplasmosis, which is an excessively large number considering the difficulty of detecting the parasite in blood. ${ }^{12}$

Additionally, in spite of highly effective antiretroviral therapy, the estimated incidence of toxoplasmic encephalitis is $15.9 \%$ in patients infected with the human immunodeficiency virus. ${ }^{13}$ Before highly effective antiretroviral therapy, encephalitis caused by $T$. gondii was the most frequent opportunistic infection complicating acquired immunodeficiency syndrome. ${ }^{14}$ Ocular toxoplasmosis is another concern with T. gondii infection, and may occur following congenital and acquired transmission; ${ }^{15}$ the risk of ocular toxoplasmosis is highly variable depending on geographic region, ranging from $2 \%$ in Europe and North America to $18 \%$ in southern Brazil.

Moreover, there are reports that $T$. gondii may be associated with psychiatric disorders, ${ }^{16}$ and may affect human behavior, personality, and other phenotypic traits. This parasite may change the behavioral phenotype of the host (mouse) to increase its likelihood of transmission to a new host (cat) by predation. ${ }^{17}$
Correspondence: João Luis Garcia Departamento de Medicina Veterinária Preventiva, Centro de Ciências Agrárias, Universidade Estadual de Londrina, CP 600I, CEP 8605I-990, Londrina-PR, Brazil

Email jlgarcia@uel.br 
The main infection sources for humans are consumption of vegetables or water contaminated with sporulated T. gondii oocysts and undercooked meat infected with tissue cysts. The risk of becoming infected depends on culinary practices, such as regular consumption of raw or undercooked meat and living in an environment with a higher risk of oocyst contamination. Those relative risks have been shown in research isolating $T$. gondii from meat and the environment. ${ }^{18-21}$ Hill et al ${ }^{22}$ recently suggested that cats were an important source of $T$. gondii infection in the USA, based on finding a low frequency of $T$. gondii in meat samples. ${ }^{23}$ In addition, Boyer et al ${ }^{24}$ showed that environmental contamination by $T$. gondii oocysts contributes substantially to acquisition of $T$. gondii and subsequent disease in people. These authors went on to suggest systematic screening of pregnant women and developing a vaccine that would have the potential to prevent the fetal disease caused by acquisition of $T$. gondii during gestation in North America.

Another important factor in the epidemiology of toxoplasmosis is the definitive host. Cats have an important role due to their close interaction with humans, and infected cats shed millions of oocysts in their feces that contaminate the environment. ${ }^{25}$ The risk of infection via sporulated oocysts in human populations has been well documented. ${ }^{20,21}$ One study showed seropositivity for immunoglobulin (Ig) $\mathrm{G}$ and IgM antibodies to $T$. gondii in human populations living in Erechim, Rio Grande do Sul, Brazil, where there was a high risk (odds ratio $>2.08$ ) of infection in individuals who have had prior contact with soil. ${ }^{21}$ In addition, an environmental survey suggested that $22.58 \%$ (7/31) of soil samples obtained from gardens in public schools in the state of São Paulo, Brazil, were positive for $T$. gondii, and found that oocysts are widely distributed in areas belonging to public schools located in the region. ${ }^{20}$ An outbreak of human toxoplasmosis was described in Santa Isabel do Ivaí, Paraná, Brazil, where about 426 people were infected, and water contaminated with $T$. gondii oocysts was considered to be the primary transmission route. ${ }^{26}$ These data demonstrate the need to control oocyst shedding by cats; however, few studies have been conducted in this regard.

Like several other parasites, $T$. gondii can be controlled by education about sanitation, management of animals, including livestock and cats, treatment, and vaccination. Treatments are available to reduce clinical signs, but there are no drugs available that kill the parasite or cure the host of infection. There is just one commercial vaccine available (Toxovax $^{\circledR}$, MSD Animal Health, Summit, NJ, USA) that is used in the UK, New Zealand, France, and Ireland. This vaccine comprises live tachyzoites of the incomplete S48 strain that has lost the ability to differentiate into tissue cysts in animals. The vaccine is licensed only for use in sheep and goats and should be administered prior to mating; however, there are some concerns about its safety because the vaccine can infect humans, and because it is a live vaccine, it has a short shelf-life. ${ }^{27}$

The aim of this paper is to discuss recent advances in the epidemiology, biology, parasite diversity, and host-parasite interactions of $T$. gondii, and to review current vaccination strategies further to the recent papers by Garcia et $\mathrm{al}^{25}$ and Innes et $\mathrm{al}^{6}$ and the prospect of future vaccines against this parasite.

\section{Invasion of cells by T. gondii}

Apicomplexan parasites, which include T. gondii, are obligate intracellular parasites. ${ }^{28}$ Invasion of cells by $T$. gondii is a very complex event and key to the survival of the parasite inside hosts, since the organism cannot multiply outside cells. ${ }^{29}$

The mechanisms via which tachyzoites invade host cells are regulated by many factors, including conoid movements, motility, and secretion of organelles (micronemes, rhoptries, and dense granules), and are calcium-dependent. ${ }^{30-32}$ This invasion is extremely rapid (15-40 seconds), depending on the sequential secretion of proteins by organelle complexes and is very important for survival of the parasite within the host cell. ${ }^{33}$ After the tachyzoite finds the host cell, it starts to excrete proteins, first from micronemes and then from rhoptries, that enable attachment of the parasite to the cell, leading to formation of a moving junction, through which the parasite enters the cell. ${ }^{34}$ Carruthers and Sibley ${ }^{35}$ compared the kinetics of secretion from apical organelles, and observed that microneme proteins are initially secreted to form the host-parasite junction. Secretion from rhoptries is then involved in formation of the parasitophorous vacuole membrane, and secretion of dense granules starts only after the parasite is inside the parasitophorous vacuole. The parasitophorous vacuole membrane is considered to be a hybrid membrane, which means that secreted-excreted proteins from the parasite will be part of this membrane, and the parasitophorous vacuole does not fuse with host endosomes or lysosomes. ${ }^{31}$

Inside the parasitophorous vacuole, the tachyzoites multiply via a process called endodyogeny. This intracellular growth by the parasite leads to rupture of infected cells and subsequent infiltrates of neutrophils, eosinophils, and mononuclear cells at the site of infection. Progression of the infection, usually by day $6,{ }^{36}$ leads to development 
of diffuse damage interrupted by multifocal necrosis. By about the third week after infection, tachyzoites start to disappear from visceral tissues and may localize as tissue cysts in neural and muscular tissues. Tachyzoites may persist longer in the spinal cord and brain than in visceral tissues because immunity is less effective in neural organs, and this persistence varies depending on the strain of $T$. gondii and the host species. ${ }^{37}$ The host immune system is activated at a very early stage after infection, with involvement of natural killer cells, interferon gamma (IFN- $\gamma$ ), and interleukin (IL)-12 macrophages, and the innate immune system creating the right microenvironment for stimulation of the specific adaptive immune system. ${ }^{38}$ As a consequence of the host immune response, the parasites are retained in tissue cysts and transform to bradyzoites, which multiply slowly within the cyst. In sheep and other livestock species, the tissue cysts can remain for the lifetime of the host, and this is also thought to be the case with humans. ${ }^{39} T$. gondii tissue cysts can be observed in the nervous system, eyes, organs, and muscles. When definitive hosts, ie, members of the cat family, become infected they shed unsporulated oocysts in their feces after a sexual phase in their intestinal cells. In the environment, unsporulated oocysts start sporogony and become sporulated (two sporocysts with four sporozoites each) and become infectious in 1-5 days depending on appropriate moist temperate environmental conditions. ${ }^{1,5}$

Host cell invasion by sporozoites differs from infection by tachyzoites and bradyzoites. Following entry of sporozoites into cells, a large parasitophorous vacuole known as PV1 is formed initially. Sporozoites are not able to replicate inside PV1, because it lacks channels allowing absorption/uptake of nutrients. Therefore, a second vacuole, PV2, is formed in the cytoplasm, the parasite transfers across, and multiplication of the parasite takes place within VP2. ${ }^{40}$

\section{Potential proteins for vaccine use}

About 1,360 specialized protein families have been described in $T$. gondii, which is a high number compared with related coccidian parasites. ${ }^{34}$ Surface antigen glycoproteins (SAGs) are important for host cell attachment and host immune evasion, and T. gondii possesses $182 \mathrm{SAG}$-related sequences distributed across 14 chromosomes at 57 genomic loci. ${ }^{41}$ Additionally, the most abundant SAGs in the stages of T. gondii (SAG1 in tachyzoites, BSRS4 in bradyzoites, and sporoSAG in sporozoites) are significantly divergent. ${ }^{35,42}$ Although SAG1 and BSR4 have different expression patterns, they are both members of the SAG1 family. Despite abundant expression of SporoSAG in infectious sporozoites, serum from patients does not contain antibodies against SporoSAG, which is a member of the SAG2 subfamily and is significantly divergent from SAG1 and BSR4. ${ }^{35,39}$

The main SAGs in T. gondii are SAG1 and SAG2, which are the most abundant proteins in tachyzoites. ${ }^{43,44}$ SAG1 is detected in the parasitophorous vacuole and in the intravacuolar membranous network; it is hydrophobic and has an acidic $\mathrm{pH} .{ }^{45} \mathrm{SAG} 1$ has a role in penetration of the host cell by the tachyzoite during the initial stage of invasion, and along with SAG2 is involved in cell adhesion and invasion. ${ }^{38,46}$ Other stages of the parasite, ie, sporozoites and bradyzoites, lose all their surface proteins during stage differentiation to the tachyzoite and show specific proteins that mediate invasion of host cells. ${ }^{38,47}$ The antigenic differences in different stages of the parasite are not fully understood, but it is speculated that surface proteins from different stages interact with different tissues/cells in the host. ${ }^{40}$ SAG1 and SAG2 have also been identified in the parasitophorous vacuole membrane and tubular vesicular network. ${ }^{48}$ Several researchers have investigated SAG1 as a candidate vaccine. ${ }^{49-57}$

As a member of the Apicomplexa phylum, T. gondii has an apical complex with specialized organelles used for host cell invasion, such as micronemes, rhoptries, and dense granules. Micronemes include adhesion proteins and a class of four aspartyl proteases (toxomepsin). Apical membrane antigen 1 (AMA1), a protein that is produced during intracellular multiplication of tachyzoites and initially localized in the microneme, ${ }^{58}$ and together with RON proteins forms a ring-like structure known as the moving junction, leads to internalization of the parasite into a parasitophorous vacuole. ${ }^{59}$ AMA1 plays a central role in host cell invasion, and antibodies against this protein block invasion of the parasite. ${ }^{60}$ The importance of this protein during the process of host cell penetration was demonstrated when a $T$. gondii AMA1 knockout strain was unable to invade host cells. ${ }^{61}$ Because of this, AMA1 is considered to be a potential vaccine candidate.

About 20 dense granule proteins from $T$. gondii have been previously described. ${ }^{62-64}$ These proteins are secreted from the parasite into the parasitophorous vacuole where they participate in the remodeling and maintenance of this compartment. Dense granule proteins may be found in the intravacuolar membranous network and the parasitophorous vacuole membrane, ${ }^{65}$ and are of fundamental importance to the survival of the parasite within the cell. ${ }^{42}$ GRA4 and GRA7 have been described also as candidate proteins for vaccine development. ${ }^{62,66,67}$

The amino acid sequence deduced for GRA4 (40 kDa) indicates a proline-rich product with an internal hydrophobic 
region and a potential site of $\mathrm{N}$-glycosylation. ${ }^{68}$ This protein was detected in serum from infected mice, providing evidence of the antigenicity of GRA4 protein synthesized from cells transfected with the plasmid DNA construct. ${ }^{69}$

Alaganan et $\mathrm{al}^{70}$ demonstrated that there is an interaction between ROP18, ROP8/2, and GRA7 leading to an increase in the virulence of T. gondii in mice. GRA7 has been shown in vitro to increase, by biochemical mechanisms, the turnover of immunity-related GTPases, thus potentially complementing the functions of other known virulence determinants, ROP18 and ROP5. This example reveals multiple layers of defense used by the parasite to counteract the innate immunity response in the host. ${ }^{70}$

There are several rhoptry proteins described to date, ${ }^{71}$ and the most abundant is the ROP2-related family, which includes ROP2, ROP3, ROP4, ROP7, and ROP8. These share antigenic determinants, a very similar molecular weight (between $55 \mathrm{kDa}$ and $60 \mathrm{kDa}$ ) and hydrophobic region(s). ${ }^{62,72}$ ROP2 is thought to serve as the molecular link between host cell mitochondria and the parasitophorous vacuole membrane. A study, which used ROP2-depleted parasites, observed that ROP2 was essential for multiplication and invasion of the parasite. ${ }^{73}$ ROP 2 was recognized by a human $\mathrm{T}$ cell clone and isolated from an immune donor, and is specific for the parasite protein and produces high levels of IFN- $\gamma \cdot{ }^{74}$ Additionally, ROP2 has been seen in all subgroups (types I, II, and III) and stages of the parasite. ${ }^{75}$ For these reasons, ROP2 was identified as a candidate vaccine, and plasmids encoding the ROP2 antigen have been used to vaccinate mice. . $^{49,76}$

Howe and Sibley ${ }^{77}$ showed that $95 \%$ of $T$. gondii strains from Europe and North America (isolates from humans with and without acquired immune deficiency syndrome and from animals) belonged to three clonal lineages (genotypes I, II, and III), indicating low genetic diversity, which is explained by infrequent recombination during replication of diploid sexual stages in the definitive host. This may be applicable in Europe and North America, but in other parts of the world, such as South America, the T. gondii strains are highly diverse. ${ }^{78}$ A recent study ${ }^{79}$ examined more than 950 isolates representing worldwide diversity, and genotyped these using three independent sets of polymorphic DNA markers, sampling 30 loci distributed across all chromosomes as well as the plastid genome. The strains clustered into 138 unique genotypes, 15 haplogroups, and six major clades. This study also indicated that a small number of ancestral lineages gave rise to the existing diversity, the predominant highly clonal lineages in the northern hemisphere, and a selection of less common genotypes showing greater evidence of recombination in parts of South America.

There are marked phenotypic variations between the genotypes; for example, while the RH strain (type I) is more virulent, ME49 (type II) and VEG (type III) are less virulent in mice. ${ }^{80}$ Analysis of complex quantitative phenotypes such as virulence has revealed that chromosome VIIa controls differences in virulence between the highly virulent type I and avirulent type III strains. Also, members of the polymorphic protein kinases, such as ROP5, ROP16, and ROP18, contribute to phenotypic differences between the genotypes. ${ }^{81-83}$ However, the importance of these variations for development of vaccines remains unknown.

\section{Immunity against T. gondii}

$T$. gondii infection rarely produces clinical signs in the host, and severity of the disease is dependent on species, age of the host, sex hormones, pregnancy, immunological status, nutritional status of the host, strain (including differences between strains ${ }^{84}$ ), parasite stage, and concomitant infection. ${ }^{85}$ The mechanisms involved in host protection against infection are components of the innate and adaptive immune responses.

Animals (laboratory, domestic, livestock) and humans are clearly not identical, and many aspects of their anatomy, physiology, and genetics are different, including the development and function of their immune systems. Basically, the process by which an immune response is generated against the parasite is the same in all species, and involves induction and function of the innate and adaptive immune responses.

Toll-like receptors (TLRs) are a family of germ lineencoded receptors of the innate immune system, via which the host recognizes pathogen-associated molecular patterns. ${ }^{86}$ In vertebrates, TLRs are essential for the recognition of parasites via the innate immune response and for induction of a clonally polarized, antigen-specific response by the adaptive immune system, mediated by B and T cells. TLRs are considered to be a conserved system, and there is no obvious interspecies variation between mammals. The nucleotide homology of human, livestock (cattle, small ruminants, pigs, horses), and domestic animal (cats, dogs) TLR genes ranges from $65 \%$ to $77 \%{ }^{87}$

Since TLRs are associated with the adaptive immune response, study of adjuvants and specific antigens from T. gondii in livestock and domestic animals and their association with TLRs might help to develop vaccines for these species. ${ }^{86}$ TLRs are essential for the development of the acquired immune response characterized by stimulation 
of naïve CD4+ helper T cells toward the Th1 or Th2 phenotype. TLR-2 contributes to the resistance to high challenged doses of T. gondii in mice, ${ }^{88}$ and TLR-11 and TLR-12 are very important in regulation of the immune response. ${ }^{89-92}$ Prominent expression of TLR-4 in the first trimester of pregnancy in humans has been reported, and lipopolysaccharide expressed in the cell wall of Gram-negative bacteria is recognized as the classic TLR-4 ligand, suggesting a possible protective role for maternally derived cells expressing these receptors. ${ }^{93}$ TLR-11 plays a dominant role in recognition of T. gondii in mice; however, TLR-11 is represented in humans only by a pseudogene, so the major question of how innate and adaptive immune responses occur in the absence of TLR11 remains unanswered..$^{92}$ Despite the lack of this functional receptor in humans, studies in knockout mice (TLR-11 ${ }^{-/-}$) show that neutrophils are a crucial source for IFN- $\gamma$, which is required for protection against T. gondii. ${ }^{94}$

Monocytes, neutrophils, and dendritic cells are recruited locally during the initial phases of infection and are important for resistance to T. gondii. This innate immune response produces the cytokine IL-12, which stimulates natural killer cells and T cells to produce the cytokine IFN- $\gamma \cdot{ }^{95} T$. gondii antigens are processed by major histocompatibility complex class II antigen-presenting cells, and their peptides are presented to $\mathrm{CD}^{+}$cells to stimulate the adaptive immune response.

Studies using knockout mice deficient in B cells, CD4+, CD8+, and cytokines have demonstrated the importance of the adaptive immune response in resistance to toxoplasmosis. ${ }^{96,97}$ In mice, extremely elevated levels of IFN- $\gamma$ and IL-18 result in lethal toxoplasmosis, whereas moderate levels of these cytokines cause nonlethal infection. Tumor necrosis factor (TNF)- $\alpha$ has an important role in resistance to toxoplasmosis, but high levels of this cytokine may contribute to pathogenesis. Elevated levels of IL-18, IFN- $\gamma$, IL-12, and TNF- $\alpha$ increase vascular permeability, and can lead to multiple organ failure and death of the animal..$^{98}$

CD4+ cells and CD8+ T lymphocytes are essential for the development of protective immunity and long-term survival during persistent infection, and this property is due to their ability to produce IFN- $\gamma$, a proinflammatory cytokine that is known to be a major mediator of resistance to $T$. gondii. ${ }^{99}$ Depletion of this cytokine during the persistent phase of $T$. gondii infection in mice showed that continued production of IFN- $\gamma$ is necessary for long-term survival. ${ }^{100}$ Extracellular tachyzoites can be destroyed in the presence of specific antibodies and complement pathway. ${ }^{101}$ Anti-T. gondii antibodies may also prevent entry of the parasite into cells.
There are many questions regarding induction of innate and adaptive immune responses during $T$. gondii infection. Most studies that have evaluated immunity against this parasite were done in murine models. However, one important issue is the clear difference between animal species regarding their susceptibility to infection, and it is unclear how we could extrapolate results from one species to another. ${ }^{39}$ Susceptibility to $T$. gondii infection may depend on differences in host-parasite interactions. This has been demonstrated in the development of toxoplasmic encephalitis in humans and mice. Human toxoplasmic encephalitis is associated with a loss of $\mathrm{T}$ cell function, whereas in mice it is associated with a defect in the $\mathrm{CD}^{+} \mathrm{T}$ cell response. ${ }^{102}$ Further, information on the immune response obtained from mice should not be extrapolated to pigs because of differences in their immune response mechanisms, such as the lack of an active nitric oxide pathway in pigs. ${ }^{103,104}$ Another important difference between animal species is found in IgM and IgG, eg, cats are not able to activate the classical complement pathway. ${ }^{105}$ The major differences between the immune systems of animal species have been described in a recent review, ${ }^{106}$ and included natural killer cells, distribution of Peyer's patches, immunoglobulin subclasses, and $\mathrm{T}$ cell receptor distribution.

\section{Vaccines against $T$. gondii}

Data obtained from Medline (PubMed, National Center for Biotechnology Information) using the key words "Toxoplasma gondii" and "vaccine", focusing on the years 2009, 2010, 2011, 2012, through September 2013, yielded approximately 109 papers addressing vaccines against $T$. gondii, comprising 26 in 2009, 15 in 2010, 26 in 2011, 20 in 2012, and 22 in 2013. Most of these studies used mice $(78 \%, 85 / 109)$ as an experimental model, six (5.5\%) used sheep, and only two $(1.8 \%)$ were in pigs. Interestingly, only one study attempted to reduce oocyst shedding in the feces of domestic cats, ${ }^{107}$ given that these animals are considered to be the key in the transmission cycle of $T$. gondii. ${ }^{27}$ Most of the mouse studies (Table 1) were conducted to test DNA vaccines (37.7\%), with the main vector used being pVAX1 (a eukaryotic expression vector), and the main vaccine candidates inserted were the SAG1, ROP2, GRA4, and MIC3 genes. Some live virus vaccines expressing recombinant proteins were evaluated, and these studies showed promising levels of protection since anti-viral responses are similar to the immune responses required to control this parasite. ${ }^{50,108}$

An important feature of $T$. gondii is that the main route of host infection is oral, with oocysts being the main form of infection in herbivores and tissue cysts being a route of 


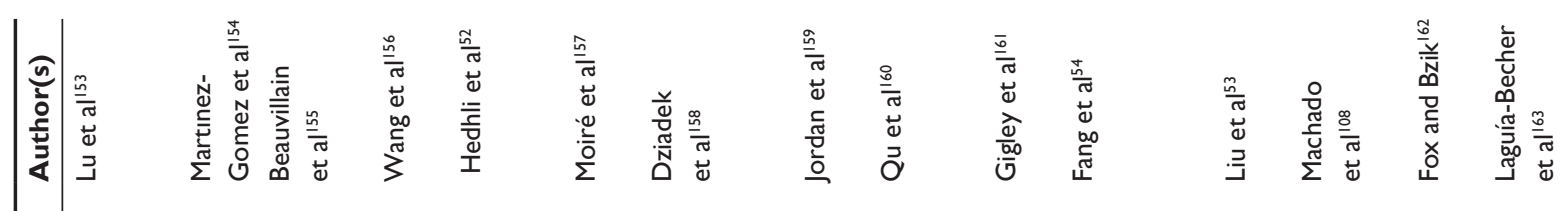

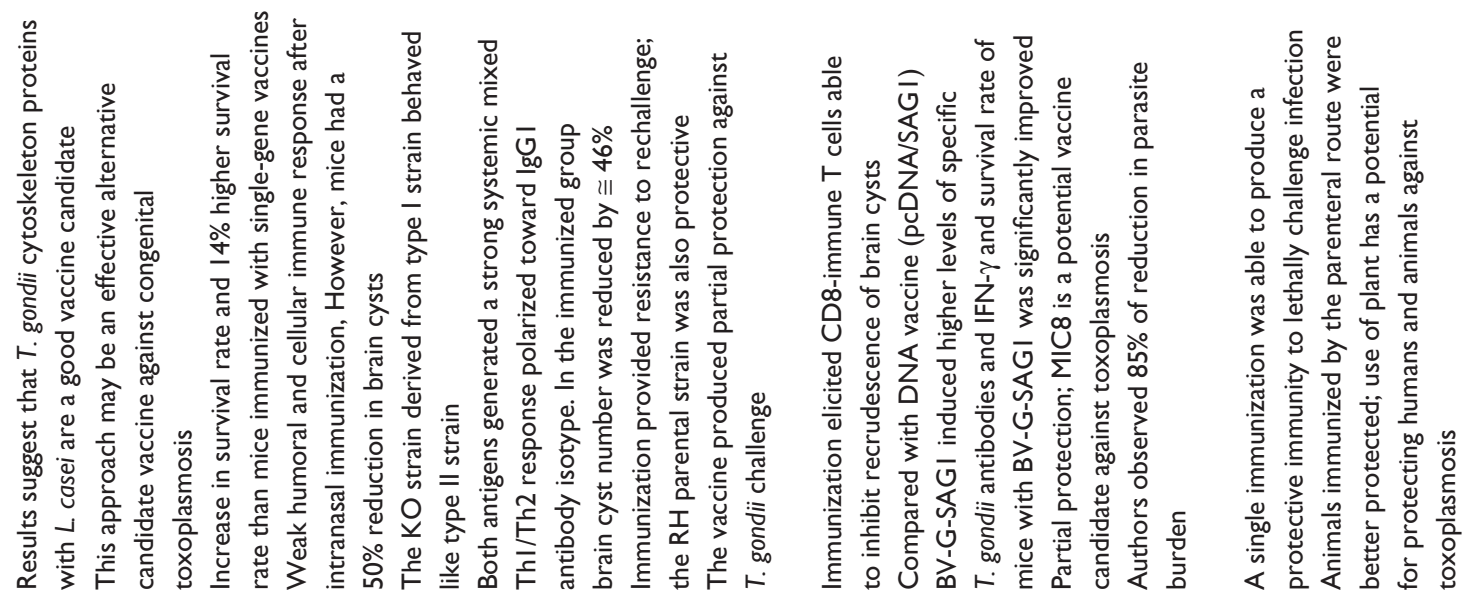

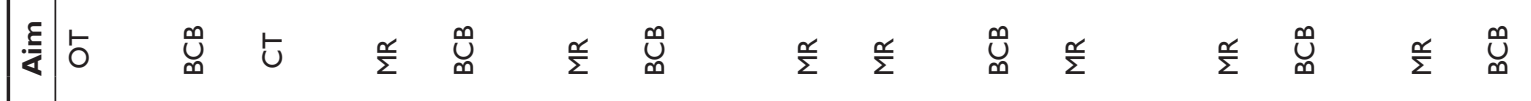

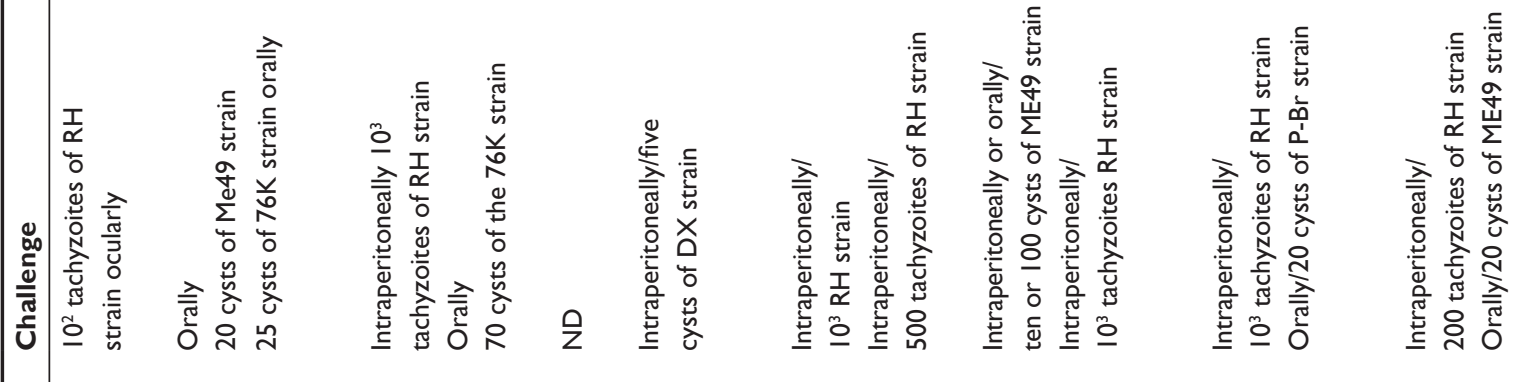
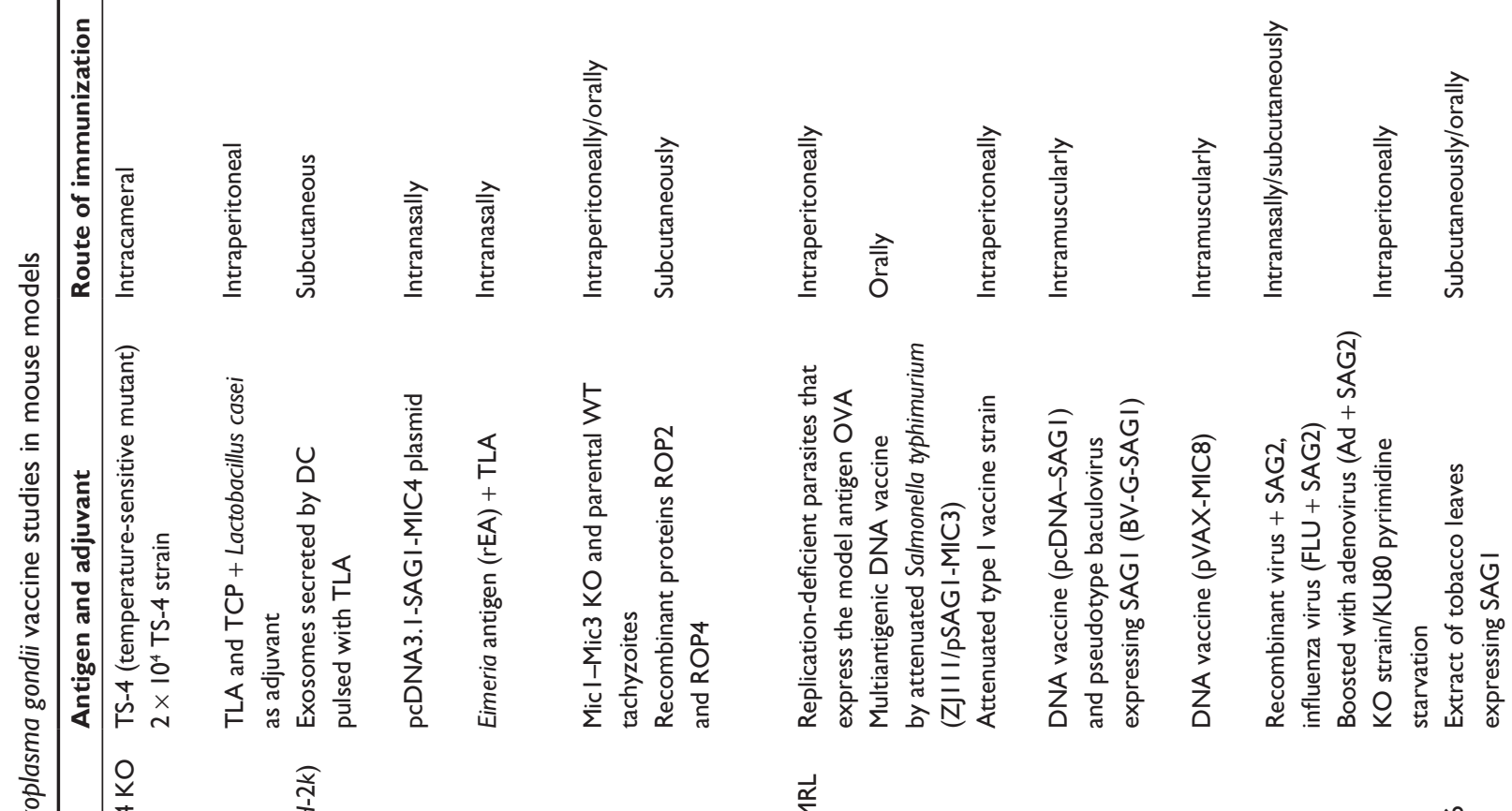

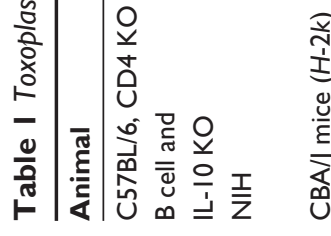

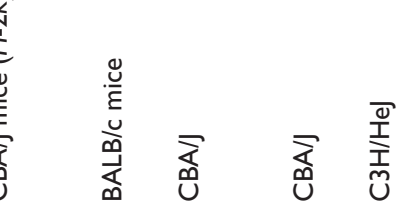

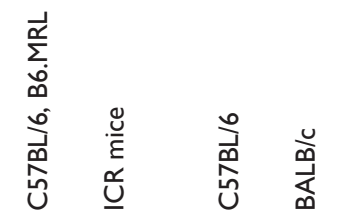

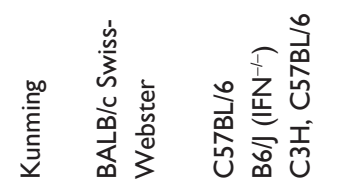




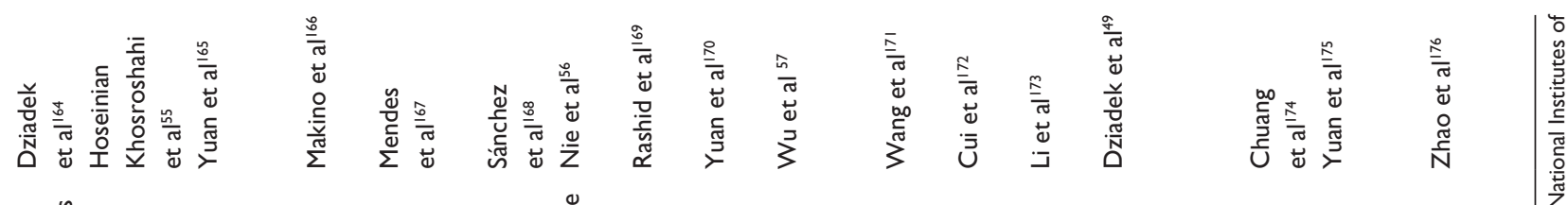

它

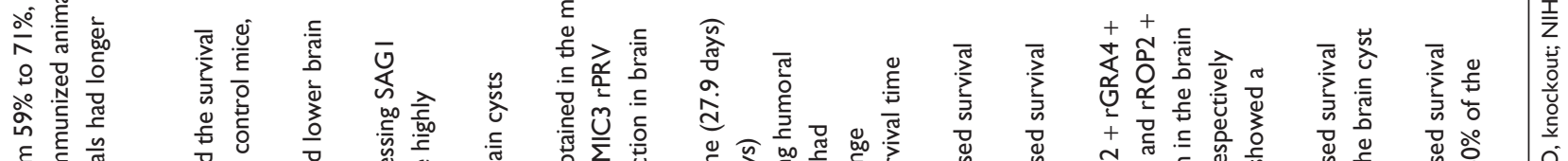

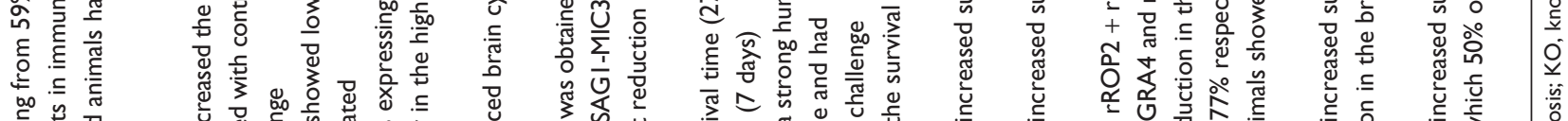

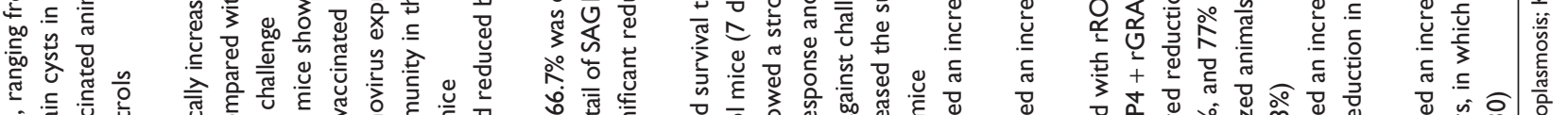

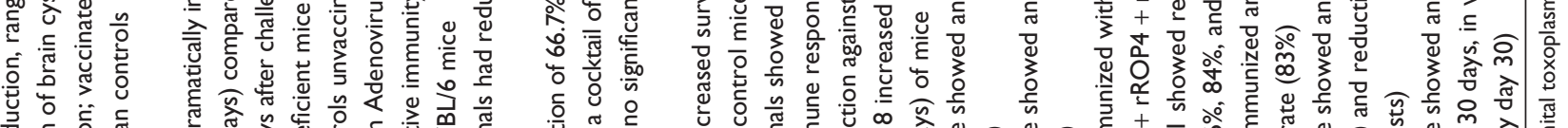

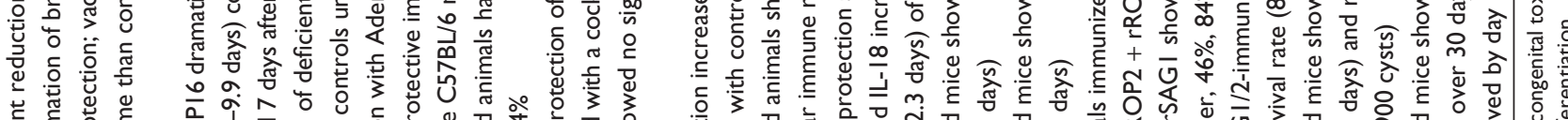

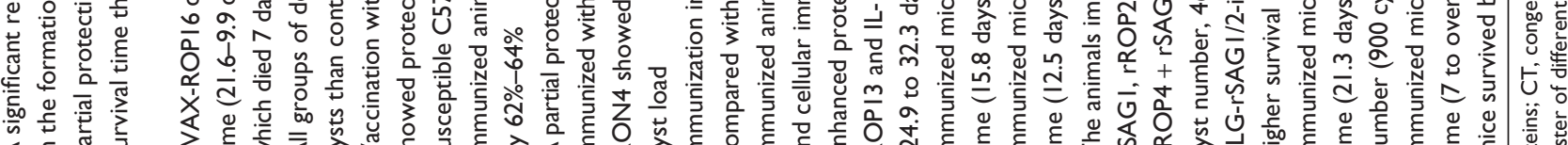

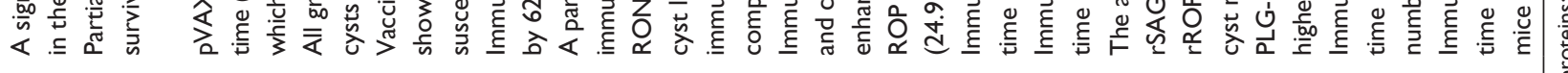

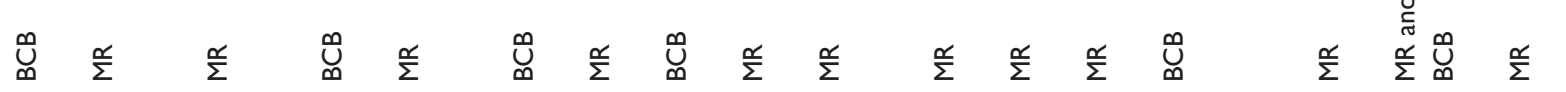

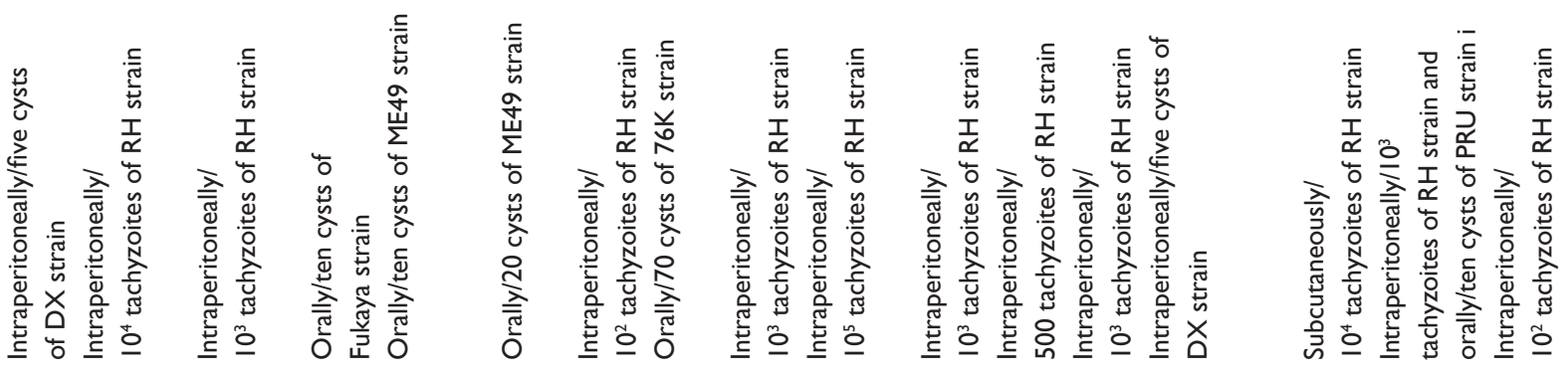

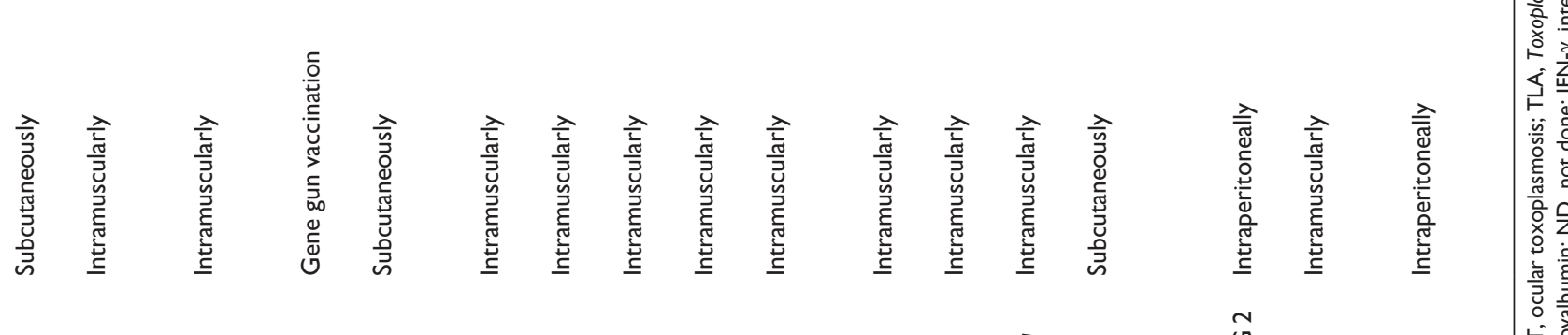

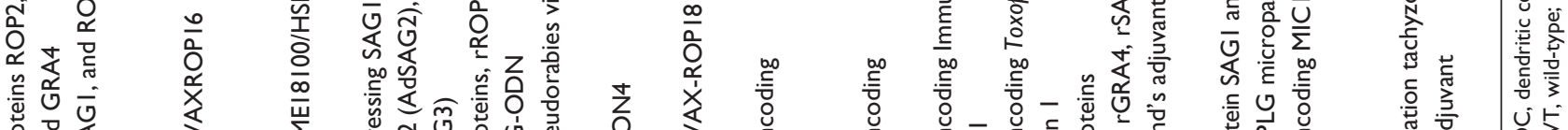

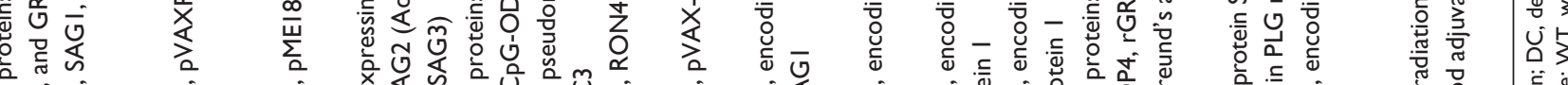

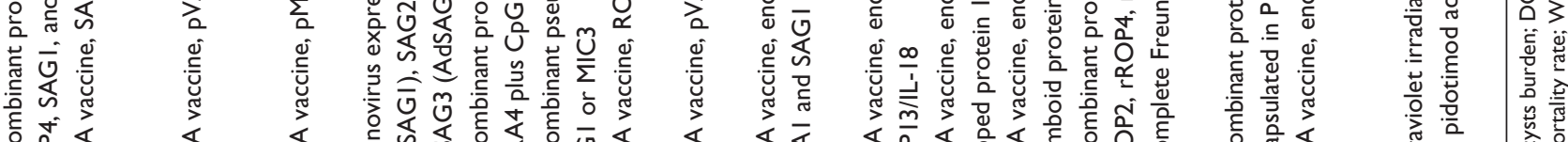

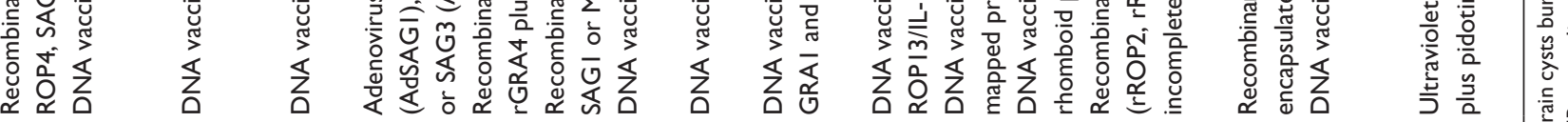

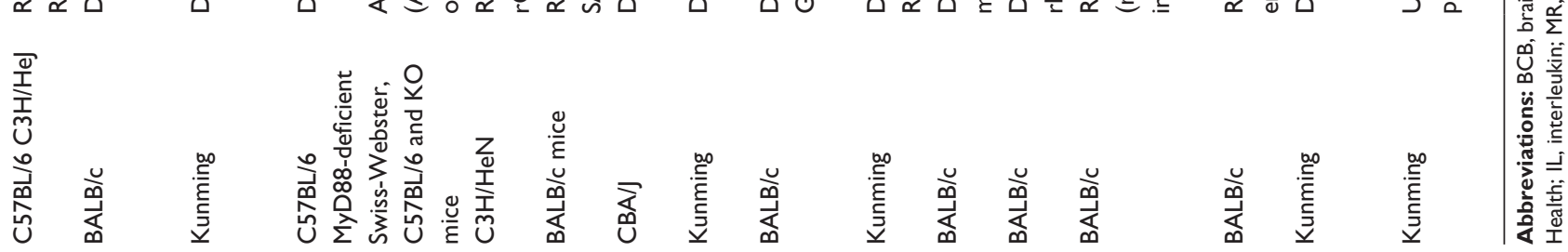


infection for pigs and humans, so local immunity in the gut via lymphocytes (mainly intraepithelial lymphocytes with $\mathrm{CD}^{+}$activity) and $\operatorname{IgA}$ is of fundamental importance in host resistance to the parasite. ${ }^{109}$ However, after initial infection by sporozoites, the parasite transforms into tachyzoites, the rapidly dividing form of the parasite, and the sporoSAG protein is nonimmunogenic during natural infection. ${ }^{110}$

\section{Livestock}

Sheep, goats, and pigs are more susceptible to disease following T. gondii infection than other livestock species and can harbor tissue cysts for life, whereas horses and cattle are less susceptible to infection and cysts containing bradyzoites are rarely detected in their tissues. ${ }^{1,39}$ However, animals raised for human consumption, including sheep, goats, chicken, cattle, horses, and pigs, are intermediate hosts and may serve as sources of $T$. gondii infection if their meat contains tissue cysts and is ingested raw or undercooked. This form of infection is described as carnivorism, ${ }^{85,111}$ and is thought to be a major transmission route for humans. Additionally, the disease burden of congenital toxoplasmosis, as represented by disability-adjusted life years, is the highest of all the food-borne pathogens. ${ }^{112}$

Toxovax is the only commercial vaccine available for congenital toxoplasmosis and is licensed for use only in sheep and goats. The manufacturer's recommendation is to use $\geq 10^{5}$ live tachyzoites of the $\mathrm{S} 48$ strain per animal. This dose should be given in a single injection of $2 \mathrm{~mL}$ via the intramuscular route at least 3 weeks prior to mating. Animals may be vaccinated from 5 months of age. The vaccine induces long-lasting immunity of at least 18 months without natural challenge. A rise in body temperature can be observed in animals following vaccination, and their meat should not be eaten for 42 days. The potential of Toxovax to prevent formation of Toxoplasma cysts in the ewe after a challenge is currently unknown.

Falcon and Freyre ${ }^{113}$ studied the capacity of a relatively low virulent strain to protect against formation of tissue cysts in sheep. Lambs were dosed orally with $10^{6}$ sporulated oocysts of the ME-49 strain, and after 45 days, were challenged orally with $4 \times 10^{6}$ sporulated oocysts of the M3 strain. Unvaccinated control animals were infected with $4 \times 10^{6}$ sporulated oocysts of the M3 strain. Using a bioassay, the authors did not observe cysts in muscle or brain tissue from lambs that were previously infected with ME49; however, unvaccinated challenged control animals showed a high burden of $T$. gondii cysts in muscle and brain tissue.
Sheep have been used as a large animal model to determine the immune response to $T$. gondii induced by a DNA vaccine. ${ }^{66,114-117}$ The antigen genes tested were expressed in dense granules and rhoptries, ie, GRA1, GRA4, GRA6, GRA7, and ROP1. These were used as DNA vaccines in different types of adjuvant formulations, such as liposomes. Ovine CD154 was added at the time of vaccination to enhance stimulation of the immune response. CD154 is expressed as a type II integral membrane protein on the surface of activated $\mathrm{T}$ cells, basophils, and mast cells. The results showed that intramuscular injection of sheep with DNA liposomes formulated to contain plasmids coding for GRA proteins is an effective system that induces a significant mixed Th1/Th2 response, while intramuscular injection of ROP1 induced a Th1-specific immune response against $T$. gondii. Li et al ${ }^{51}$ investigated the immune response in sheep after injection of plasmids encoding $T$. gondii SAG1 and ROP1. Injection of ROP1 produced a better immune response than SAG1. However, these studies did not indicate sufficient protection against $T$. gondii challenge.

Mevelec et $\mathrm{al}^{118}$ showed the effectiveness of a mic1 and mic3 gene knockout (Mic1-3 KO) RH strain against Toxoplasma abortion in sheep. Sheep were inoculated subcutaneously with $10^{5} \mathrm{Mic1}-3 \mathrm{KO}$ tachyzoites, and showed a mild febrile and parasite-specific IgG antibody response. Ewes were mated 2 months after vaccination and were challenged orally at mid gestation with different doses of oocysts from the PRU strain (100-400 sporulated oocysts). After challenge, the animals showed a slight febrile response, whereas unvaccinated ewes developed a more severe febrile response. All unvaccinated ewes aborted, while 62\%-91\% of lambs born to the vaccinated sheep were viable, and did not show clinical signs of infection. The authors tested the Toxovax (S48 strain) vaccine as well, and showed that the mutant strain was as effective as the S48 strain. The mutant strain, at a dose of $10^{5}$ tachyzoites, induced a level of protection comparable with that of $2 \times 10^{6} \mathrm{~S} 48$ tachyzoites.

There are only three studies that have attempted to vaccinate goats against toxoplasmosis. ${ }^{119-121}$ Two of these studies ${ }^{119,120}$ used goats with related parasites (Hammondia hammondi) and $H$. heydorni to protect against congenital toxoplasmosis in does, and reported partial protection using $H$. hammondi but no promising effect using $H$. heydorni. The last study ${ }^{121}$ show good efficacy of the S48 strain in protecting does against congenital infection in France, one of the countries in which Toxovax is licensed. It is still necessary to conduct more studies using this host in vaccine experiments, given that goats are one of the species most 
susceptible to T. gondii infection. ${ }^{122}$ Moreover, consumption of $T$. gondii-infected raw or undercooked goat meat and unpasteurized goat milk containing tachyzoites constitutes a significant infection risk in humans. ${ }^{123-125}$

Clinical signs of toxoplasmosis in pigs are considered rare, and abortion in sows is not common but can occur. ${ }^{126,127}$ Tissue cysts in pork can persist for more than 2 years, and these are one of the most important sources of $T$. gondii infection in humans. ${ }^{23,128}$ Because of the potential public health risk from undercooked infected pork, a vaccine for pigs needs to be able to reduce or prevent formation of tissue cysts.

Verhelst et al ${ }^{129}$ showed that GRA7 and MIC3 were able to induce a good humoral immune response in pigs experimentally challenged with $T$. gondii tissue cysts. Cunha et al $^{130}$ evaluated protection against formation of tissue cysts in pigs immunized intranasally with a crude rhoptry protein preparation of $T$. gondii plus Quil- ${ }^{\circledR}$. The vaccinated and challenged group showed $41.6 \%$ protection against tissue cyst formation versus $6.5 \%$ protection in the adjuvant control group.

Excreted-secreted antigens (proteins discharged from organelles of the parasite during invasion of host cells) from T. gondii mixed with Freund's adjuvant were used as a vaccine in pigs to evaluate the humoral and cellular immune response and protection against an intraperitoneal challenge with $10^{7}$ tachyzoites of the GJS strain. ${ }^{131}$ The authors showed a cellular immune response associated with production of IFN- $\gamma$ and IL-4, and a humoral response mainly against antigens with molecular masses of 34-116 kDa. Following challenge, the immunized pigs remained clinically normal except for a rise in temperature, while the control pigs developed higher fever and clinical signs of toxoplasmosis. A reduction in formation of tissue cysts in muscles was found in the vaccinated animals.

\section{Cats}

Felines are the only definitive hosts able to shed oocysts via their feces, and domestic cats play an important role in the transmission of $T$. gondii. Cats are widespread globally and are considered to be among the worst non-native invasive species in the world. Moreover, they live in close proximity to humans. ${ }^{132}$ Infected cats can shed millions of oocysts in their feces, ${ }^{25}$ that may contaminate soil, water, and food. The significance of the environmental spread of oocysts produced by wild cats is unknown.

The first studies to immunize cats to prevent oocyst shedding were reported by Frenkel et al ${ }^{133}$ and Freyre et al. ${ }^{134}$ These authors, along with Mateus-Pinilla et al, ${ }^{135}$ used a
T-263 strain that had been transformed in the laboratory and lost the ability to complete the sexual cycle in enteroepithelial cells in cats as a vaccine. The main concern about use of the T-263 strain as a vaccine is its short shelf-life and need for production in mice. 60Co-irradiation tachyzoites were tested in cats in order to prevent/reduce oocyst shedding; however, the authors did not observe a significant reduction in oocysts in the vaccinated cats. ${ }^{136,137}$ Garcia et al, ${ }^{25}$ and more recently Zulpo et al, ${ }^{107}$ tested a vaccine based on rhoptry proteins administered by the intranasal and rectal routes in cats and found that the immunized animals eliminated $90.8 \%$ and $98 \%$ fewer oocysts than the control group, respectively.

\section{Mice}

Mice are the experimental model of choice for Toxoplasma vaccine studies, as shown in Table 1. They are easier to manipulate and inexpensive to maintain compared with domestic and livestock animals, and their immunology is very well characterized. Many studies have used mice to investigate vaccines (Table 1). However, comparison of their results is difficult because of the different types of immunization, challenge routes (with different forms of parasite), and mouse strains used. Several types of approach have been used, ie, attenuated live vaccines, knockout strains, DNA vaccines, attenuated recombinant viruses, and recombinant proteins, and all described partial protection, mainly against mortality due to acute infection and tissue cyst burden.

\section{Biological models for vaccine studies}

Mice and rats are the main biological models used to study toxoplasmosis in vivo. While mice are sensitive, rats, like humans, are relatively resistant to $T$. gondii. Murine susceptibility to $T$. gondii is under multigenic control, with at least one of the genes linked to the major histocompatibility complex (H2 locus). ${ }^{138}$ In addition, reduction of cyst numbers in the brain and encephalitis is mediated by the $L^{d}$ gene in the $\mathrm{D}$ region of the $\mathrm{H} 2$ complex in mice. ${ }^{139}$

Sequencing the mouse genome has shown that approximately $99 \%$ of mouse genes have a homolog in the human genome. ${ }^{140}$ However, there are differences between the immune systems of mice and humans ${ }^{141,142}$ and between mice and domestic animals. ${ }^{86,106}$ These differences need to be considered before data obtained from mice can be extrapolated to humans or domestic animals.

Mice are useful for in vivo vaccine studies against T. gondii, and with the availability of knockout gene mouse 
strains, they will continue to be the first choice for vaccine trials. Other animal models of human toxoplasmosis have been used, including the rabbit, ${ }^{143}$ hamster, ${ }^{144,145}$ sheep, ${ }^{146,147}$ and pig. ${ }^{130,148,149}$ However, extrapolation of the results observed in experiments with animals is a difficult task, and a good biological model for ocular, congenital, recrudescence, and acute and persistent $T$. gondii infection would be very helpful in the prevention of human toxoplasmosis.

\section{Prospects for future vaccines}

Vaccination against bacterial and viral diseases is widespread, routine, and successful, but only a few vaccines for veterinary protozoan diseases have been developed successfully, and thus far none are available for human use. Future studies aiming to develop $T$. gondii vaccines should focus on parasite antigens able to trigger a protective immune response and investigate immunization routes and vaccine delivery strategies. To be effective, a protective vaccine needs to stimulate both humoral and cellular immune responses, which is difficult to achieve with killed vaccines. Concerns regarding live vaccines are mainly to do with their safety and short shelf-life. It would also be desirable to create a vaccine that would enable differentiation between vaccinated and infected animals. Thus, the use of viruses as vectors and knockout strains could be a good strategy to develop vaccines against this parasite.

Based on disability-adjusted life-year papers, T. gondii is considered one of the most significant food-borne pathogens, ${ }^{112,150}$ and there is no treatment that is able to eliminate the parasite from human tissue; this is important when considering the brain (psychiatric disorders and toxoplasmic encephalitis) and eye (ocular disease), and what enforces the development of a vaccine against this parasite.

Use of relevant animal species is important in the study of protective immune responses to $T$. gondii, because they address questions relating to specific host-parasite interactions. More studies should be done using cats in order to answer important questions, such as: Which approach should be used to achieve an intestinal immune response against $T$. gondii to diminish oocyst shedding, ie, live or killed vaccines? What is the best route of immunization, ie, systemic or oral? Which proteins should be used in recombinant vaccines? What is the potential of cats to reshed oocysts after reinfection? Do different genotypes induce/require a different immune response?

Goats are one of the most susceptible domestic animal species with respect to toxoplasmosis, and the main clinical signs in adult goats are reproductive disorders, although some animals may develop anorexia, prostration, fever, and mastitis. ${ }^{151,152}$ Unfortunately, very few studies that have attempted to produce a vaccine against $T$. gondii for goats. Further, despite Toxovax being licensed for use in does, it is only available in a limited number of countries, so there is a need for more studies looking at developing vaccines in goats.

Information obtained so far indicates that future vaccines for $T$. gondii should be developed against several different targets, ie, to prevent oocyst shedding by cats, prevent formation of tissue cysts in animals raised for human consumption, and prevent abortion or fetal malformation in sheep, goats, and women.

A vaccine against ocular toxoplasmosis as a consequence of acquired infection in regions with a high level of ocular toxoplasmosis, such as southern Brazil, should also be addressed. Development of a type of immunomodulator to be used in patients with chronic ocular toxoplasmosis could be a good approach to avoid future reactivation.

\section{Acknowledgments}

The authors would like to thank the Coordenação de Aperfeicoamento de Pessoal de Nivel Superior (CAPES 10259-12-0) and Conselho Nacional de Desenvolvimentio Cientifico eTecnologico(CNPq, 474924/2011-4;303901/2012-8), the Scottish Government (Rural and Environment Science and Analytical Services), and the Moredun Foundation and Creative Science Company for financial support.

\section{Disclosure}

The authors report no conflicts of interest in this work.

\section{References}

1. Dubey JP, Thulliez P. Persistence of tissue cysts in edible tissues of cattle fed Toxoplasma gondii oocysts. Am J Vet Res. 1993;54(2):270-273.

2. Prestrud KW, Dubey JP, Asbakk K, Fuglei E, Su C. First isolate of Toxoplasma gondii from arctic fox (Vulpes lagopus) from Svalbard. Vet Parasitol. 2008;151(2-4):110-114.

3. Canon-Franco WA, Araujo FA, Lopez-Orozco N, et al. Toxoplasma gondii in free-ranging wild small felids from Brazil: molecular detection and genotypic characterization. Vet Parasitol. 2013;197(3-4):462-469.

4. Nieto SO, Melendez RD. Seroprevalence of Toxoplasma gondii in goats from arid zones of Venezuela. J Parasitol. 1998;84(1):190-191.

5. Dubey JP, Fair PA, Sundar N, et al. Isolation of Toxoplasma gondii from bottlenose dolphins (Tursiops truncatus). J Parasitol. 2008;94(4): 821-823.

6. Innes EA, Bartley PM, Maley S, Katzer F, Buxton D. Veterinary vaccines against Toxoplasma gondii. Mem Inst Oswaldo Cruz. 2009;104(2): 246-251.

7. Carellos EV, Caiaffa WT, Andrade GM, Abreu MN, Januario JN. Congenital toxoplasmosis in the state of Minas Gerais, Brazil: a neglected infectious disease? Epidemiol Infect. 2013:1-12.

8. Jones JL, Lopez A, Wilson M, Schulkin J, Gibbs R. Congenital toxoplasmosis: a review. Obstet Gynecol Surv. 2001;56(5):296-305.

9. Tenter AM, Heckeroth AR, Weiss LM. Toxoplasma gondii: from animals to humans. Int J Parasitol. 2000;30(12-13):1217-1258. 
10. Freyre A, Falcon J, Mendez J, Rodriguez A, Correa L, Gonzalez M. Toxoplasma gondii: partial cross-protection among several strains of the parasite against congenital transmission in a rat model. Exp Parasitol. 2006;112(1):8-12.

11. Dubey JP. Strategies to reduce transmission of Toxoplasma gondii to animals and humans. Vet Parasitol. 1996;64(1-2):65-70.

12. Carneiro AC, Andrade GM, Costa JG, et al. Genetic characterization of Toxoplasma gondii revealed highly diverse genotypes for isolates from newborns with congenital toxoplasmosis in southeastern Brazil. J Clin Microbiol. 2013;51(3):901-907.

13. Leport C, Franck J, Chene G, et al. Immunoblot profile as predictor of toxoplasmic encephalitis in patients infected with human immunodeficiency virus. Clin Diagn Lab Immunol. 2001;8(3): 579-584.

14. Luft BJ, Hafner R, Korzun AH, et al. Toxoplasmic encephalitis in patients with the acquired immunodeficiency syndrome. Members of the ACTG 077p/ANRS 009 Study Team. N Engl J Med. 1993;329(14): 995-1000.

15. Silveira C, Belfort R Jr, Muccioli C, et al. A follow-up study of Toxoplasma gondii infection in southern Brazil. Am J Ophthalmol. 2001;131(3):351-354.

16. Carter CJ. Toxoplasmosis and polygenic disease susceptibility genes: extensive Toxoplasma gondii host/pathogen interactome enrichment in nine psychiatric or neurological disorders. J Pathog. 2013;2013:965046.

17. Flegr J. Influence of latent Toxoplasma infection on human personality, physiology and morphology: pros and cons of the Toxoplasma-human model in studying the manipulation hypothesis. J Exp Biol. 2013 216 Pt 1:127-133.

18. Navarro IT, Vidotto O, Giraldi N, Mitsuka R. [Resistance of Toxoplasma gondii to sodium chloride and condiments in pork sausage]. Bol Oficina Sanit Panam. 1992;112(2):138-143. Portuguese.

19. Dias RA, Navarro IT, Ruffolo BB, Bugni FM, Castro MV, Freire RL. Toxoplasma gondii in fresh pork sausage and seroprevalence in butchers from factories in Londrina, Parana State, Brazil. Rev Inst Med Trop Sao Paulo. 2005;47(4):185-189.

20. dos Santos TR, Nunes CM, Luvizotto MC, et al. Detection of Toxoplasma gondii oocysts in environmental samples from public schools. Vet Parasitol. 2010;171(1-2):53-57.

21. Jones JL, Muccioli C, Belfort R Jr, Holland GN, Roberts JM, Silveira C. Recently acquired Toxoplasma gondii infection, Brazil. Emerg Infect Dis. 2006;12(4):582-587.

22. Hill D, Coss C, Dubey JP, et al. Identification of a sporozoite-specific antigen from Toxoplasma gondii. J Parasitol. 2011;97(2):328-337.

23. Dubey JP, Hill DE, Jones JL, et al. Prevalence of viable Toxoplasma gondii in beef, chicken, and pork from retail meat stores in the United States: risk assessment to consumers. J Parasitol. 2005;91(5):1082-1093.

24. Boyer K, Hill D, Mui E, et al. Unrecognized ingestion of Toxoplasma gondii oocysts leads to congenital toxoplasmosis and causes epidemics in North America. Clin Infect Dis. 2011;53(11):1081-1089.

25. Garcia JL, Navarro IT, Biazzono L, et al. Protective activity against oocyst shedding in cats vaccinated with crude rhoptry proteins of the Toxoplasma gondii by the intranasal route. Vet Parasitol. 2007;145(3-4): 197-206.

26. de Moura L, Bahia-Oliveira LM, Wada MY, et al. Waterborne toxoplasmosis, Brazil, from field to gene. Emerg Infect Dis. 2006;12(2): 326-329.

27. Garcia JL. Vaccination concepts against Toxoplasma gondii. Expert Rev Vaccines. 2009;8(2):215-225.

28. Etzion Z, Murray MC, Perkins ME. Isolation and characterization of rhoptries of Plasmodium falciparum. Mol Biochem Parasitol. 1991;47(1):51-61.

29. Saffer LD, Schwartzman JD. A soluble phospholipase of Toxoplasma gondii associated with host cell penetration. J Protozool. 1991;38(5): 454-460.

30. Nichols BA, Chiappino ML. Cytoskeleton of Toxoplasma gondii. J Protozool. 1987;34(2):217-226.
31. Bonhomme A, Bouchot A, Pezzella N, Gomez J, Le Moal H, Pinon JM. Signaling during the invasion of host cells by Toxoplasma gondii. FEMS Microbiol Rev. 1999;23(5):551-561.

32. Bouchot A, Zierold K, Bonhomme A, et al. Tachyzoite calcium changes during cell invasion by Toxoplasma gondii. Parasitol Res. 1999;85(10): 809-818.

33. Hoff EF, Carruthers VB. Is Toxoplasma egress the first step in invasion? Trends Parasitol. 2002;18(6):251-255.

34. Wasmuth J, Daub J, Peregrin-Alvarez JM, Finney CA, Parkinson J. The origins of apicomplexan sequence innovation. Genome Res. 2009;19(7): 1202-1213.

35. Carruthers VB, Sibley LD. Sequential protein secretion from three distinct organelles of Toxoplasma gondii accompanies invasion of human fibroblasts. Eur J Cell Biol. 1997;73(2):114-123.

36. Parker GA, Langloss JM, Dubey JP, Hoover EA. Pathogenesis of acute toxoplasmosis in specific-pathogen-free cats. Vet Pathol. 1981;18(6): 786-803.

37. Dubey JP, Lago EG, Gennari SM, Su C, Jones JL. Toxoplasmosis in humans and animals in Brazil: high prevalence, high burden of disease, and epidemiology. Parasitology. 2012;139(11):1375-1424.

38. Dupont CD, Christian DA, Hunter CA. Immune response and immunopathology during toxoplasmosis. Semin Immunopathol. 2012;34(6): 793-813.

39. Innes EA. Toxoplasmosis: comparative species susceptibility and host immune response. Comp Immunol Microbiol Infect Dis. 1997;20(2): $131-138$.

40. Tilley M, Fichera ME, Jerome ME, Roos DS, White MW. Toxoplasma gondii sporozoites form a transient parasitophorous vacuole that is impermeable and contains only a subset of dense-granule proteins. Infect Immun. 1997;65(11):4598-4605.

41. Wasmuth JD, Pszenny V, Haile S, et al. Integrated bioinformatic and targeted deletion analyses of the SRS gene superfamily identify SRS29C as a negative regulator of Toxoplasma virulence. MBio. 2012;3(6).

42. Crawford J, Grujic O, Bruic E, Czjzek M, Grigg ME, Boulanger MJ. Structural characterization of the bradyzoite surface antigen (BSR4) from Toxoplasma gondii, a unique addition to the surface antigen glycoprotein 1-related superfamily. J Biol Chem. 2009;284(14): 9192-9198.

43. Couvreur G, Sadak A, Fortier B, Dubremetz JF. Surface antigens of Toxoplasma gondii. Parasitology. 1988;97 Pt 1:1-10.

44. Grimwood J, Smith JE. Toxoplasma gondii: the role of parasite surface and secreted proteins in host cell invasion. Int J Parasitol. 1996;26(2): $169-173$.

45. McLeod R, Mack D, Brown C. Toxoplasma gondii - new advances in cellular and molecular biology. Exp Parasitol. 1991;72(1): 109-121.

46. Grimwood J, Mineo JR, Kasper LH. Attachment of Toxoplasma gondii to host cells is host cell cycle dependent. Infect Immun. 1996;64(10): 4099-4104.

47. Gross U, Bohne W, Soete M, Dubremetz JF. Developmental differentiation between tachyzoites and bradyzoites of Toxoplasma gondii. Parasitol Today. 1996;12(1):30-33.

48. Achbarou A, Mercereau-Puijalon O, Sadak A, et al. Differential targeting of dense granule proteins in the parasitophorous vacuole of Toxoplasma gondii. Parasitology. 1991;103 Pt 3:321-329.

49. Dziadek B, Gatkowska J, Grzybowski M, Dziadek J, Dzitko K, Dlugonska $\mathrm{H}$. Toxoplasma gondii: the vaccine potential of three trivalent antigen-cocktails composed of recombinant ROP2, ROP4, GRA4 and SAG1 proteins against chronic toxoplasmosis in BALB/c mice. Exp Parasitol. 2012;131(1):133-138.

50. Shang L, Liu Q, Liu W, et al. Protection in mice immunized with a heterologous prime-boost regime using DNA and recombinant pseudorabies expressing TgSAG1 against Toxoplasma gondii challenge. Vaccine. 2009;27(21):2741-2745.

51. Li B, Oledzka G, McFarlane RG, et al. Immunological response of sheep to injections of plasmids encoding Toxoplasma gondii SAG1 and ROP1 genes. Parasite Immunol. 2010;32(9-10):671-683. 
52. Hedhli D, Dimier-Poisson I, Judge JW, Rosenberg B, Mevelec MN. Protective immunity against Toxoplasma challenge in mice by coadministration of T. gondii antigens and Eimeria profilin-like protein as an adjuvant. Vaccine. 2009;27(16):2274-2281.

53. Liu Q, Shang L, Jin H, Wei F, Zhu XQ, Gao H. The protective effect of a Toxoplasma gondii SAG1 plasmid DNA vaccine in mice is enhanced with IL-18. Res Vet Sci. 2010;89(1):93-97.

54. Fang R, Feng H, Nie H, et al. Construction and immunogenicity of pseudotype baculovirus expressing Toxoplasma gondii SAG1 protein in BALB/c mice model. Vaccine. 2010;28(7):1803-1807.

55. Hoseinian Khosroshahi K, Ghaffarifar F, D’Souza S, Sharifi Z, Dalimi A. Evaluation of the immune response induced by DNA vaccine cocktail expressing complete SAG1 and ROP2 genes against toxoplasmosis. Vaccine. 2011;29(4):778-783.

56. Nie H, Fang R, Xiong BQ, et al. Immunogenicity and protective efficacy of two recombinant pseudorabies viruses expressing Toxoplasma gondii SAG1 and MIC3 proteins. Vet Parasitol. 2011;181(2-4):215-221.

57. Wu XN, Lin J, Lin X, Chen J, Chen ZL, Lin JY. Multicomponent DNA vaccine-encoding Toxoplasma gondii GRA1 and SAG1 primes: antiToxoplasma immune response in mice. Parasitol Res. 2012;111(5): 2001-2009.

58. Hehl AB, Lekutis C, Grigg ME, et al. Toxoplasma gondii homologue of plasmodium apical membrane antigen 1 is involved in invasion of host cells. Infect Immun. 2000;68(12):7078-7086.

59. Tonkin ML, Roques M, Lamarque MH, et al. Host cell invasion by apicomplexan parasites: insights from the co-structure of AMA1 with a RON2 peptide. Science. 2011;333(6041):463-467.

60. Hodder AN, Crewther PE, Anders RF. Specificity of the protective antibody response to apical membrane antigen 1. Infect Immun. 2001;69(5):3286-3294.

61. Mital J, Meissner M, Soldati D, Ward GE. Conditional expression of Toxoplasma gondii apical membrane antigen-1 (TgAMA1) demonstrates that TgAMA1 plays a critical role in host cell invasion. Mol Biol Cell. 2005;16(9):4341-4349.

62. Leriche MA, Dubremetz JF. Characterization of the protein contents of rhoptries and dense granules of Toxoplasma gondii tachyzoites by subcellular fractionation and monoclonal antibodies. Mol Biochem Parasitol. 1991;45(2):249-259.

63. Metsis A, Pettsersen E, Petersen E. Toxoplasma gondii: characterization of a monoclonal antibody recognizing antigens of 36 and $38 \mathrm{kDa}$ with acid phosphatase activity located in dense granules and rhoptries. Exp Parasitol. 1995;81(4):472-479.

64. Okada T, Marmansari D, Li ZM, et al. A novel dense granule protein, GRA22, is involved in regulating parasite egress in Toxoplasma gondii. Mol Biochem Parasitol. 2013;189(1-2):5-13.

65. Masatani T, Matsuo T, Tanaka T, et al. TgGRA23, a novel Toxoplasma gondii dense granule protein associated with the parasitophorous vacuole membrane and intravacuolar network. Parasitol Int. 2013;62(4): $372-379$.

66. Hiszczynska-Sawicka E, Oledzka G, Holec-Gasior L, et al. Evaluation of immune responses in sheep induced by DNA immunization with genes encoding GRA1, GRA4, GRA6 and GRA7 antigens of Toxoplasma gondii. Vet Parasitol. 2011;177(3-4):281-289.

67. Jongert E, Melkebeek V, De Craeye S, Dewit J, Verhelst D, Cox E. An enhanced GRA1-GRA7 cocktail DNA vaccine primes anti-Toxoplasma immune responses in pigs. Vaccine. 2008;26(8):1025-1031.

68. Mevelec MN, Chardes T, Mercereau-Puijalon O, et al. Molecular cloning of GRA4, a Toxoplasma gondii dense granule protein, recognized by mucosal IgA antibodies. Mol Biochem Parasitol. 1992;56(2):227-238.

69. Desolme B, Mevelec MN, Buzoni-Gatel D, Bout D. Induction of protective immunity against toxoplasmosis in mice by DNA immunization with a plasmid encoding Toxoplasma gondii GRA4 gene. Vaccine. 2000;18(23):2512-2521.

70. Alaganan A, Fentress SJ, Tang K, Wang Q, Sibley LD. Toxoplasma GRA7 effector increases turnover of immunity-related GTPases and contributes to acute virulence in the mouse. Proc Natl Acad Sci U SA. 2014;111(3):1126-1131.
71. Camejo A, Gold DA, Lu D, et al. Identification of three novel Toxoplasma gondii rhoptry proteins. Int J Parasitol. 2014;44(2):147-160.

72. Beckers CJ, Dubremetz JF, Mercereau-Puijalon O, Joiner KA. The Toxoplasma gondii rhoptry protein ROP 2 is inserted into the parasitophorous vacuole membrane, surrounding the intracellular parasite, and is exposed to the host cell cytoplasm. J Cell Biol. 1994;127(4):947-961.

73. Nakaar V, Ngo HM, Aaronson EP, Coppens I, Stedman TT, Joiner KA. Pleiotropic effect due to targeted depletion of secretory rhoptry protein ROP2 in Toxoplasma gondii. J Cell Sci. 2003;116 Pt 11:2311-2320.

74. Saavedra R, de Meuter F, Decourt JL, Herion P. Human T cell clone identifies a potentially protective $54-\mathrm{kD}$ a protein antigen of Toxoplasma gondii cloned and expressed in Escherichia coli. J Immunol. 1991;147(6):1975-1982.

75. El Hajj H, Demey E, Poncet J, et al. The ROP2 family of Toxoplasma gondii rhoptry proteins: proteomic and genomic characterization and molecular modeling. Proteomics. 2006;6(21):5773-5784.

76. Vercammen M, Scorza T, Huygen K, et al. DNA vaccination with genes encoding Toxoplasma gondii antigens GRA1, GRA7, and ROP2 induces partially protective immunity against lethal challenge in mice. Infect Immun. 2000;68(1):38-45.

77. Howe DK, Sibley LD. Toxoplasma gondii comprises three clonal lineages: correlation of parasite genotype with human disease. J Infect Dis. 1995;172(6):1561-1566.

78. Dubey JP, Sundar N, Gennari SM, et al. Biologic and genetic comparison of Toxoplasma gondii isolates in free-range chickens from the northern Para state and the southern state Rio Grande do Sul, Brazil revealed highly diverse and distinct parasite populations. Vet Parasitol. 2007;143(2):182-188.

79. Su C, Khan A, Zhou P, et al. Globally diverse Toxoplasma gondii isolates comprise six major clades originating from a small number of distinct ancestral lineages. Proc Natl Acad Sci U S A. 2012;109(15):5844-5849.

80. Sibley LD, Boothroyd JC. Virulent strains of Toxoplasma gondii comprise a single clonal lineage. Nature. 1992;359(6390):82-85.

81. Behnke MS, Khan A, Wootton JC, Dubey JP, Tang K, Sibley LD. Virulence differences in Toxoplasma mediated by amplification of a family of polymorphic pseudokinases. Proc Natl Acad Sci U S A. 2011;108(23):9631-9636.

82. Su C, Howe DK, Dubey JP, Ajioka JW, Sibley LD. Identification of quantitative trait loci controlling acute virulence in Toxoplasma gondii. Proc Natl Acad Sci U S A. 2002;99(16):10753-10758.

83. Taylor S, Barragan A, Su C, et al. A secreted serine-threonine kinase determines virulence in the eukaryotic pathogen Toxoplasma gondii. Science. 2006;314(5806):1776-1780.

84. Howe DK, Sibley LD. Toxoplasma gondii: analysis of different laboratory stocks of the RH strain reveals genetic heterogeneity. Exp Parasitol. 1994;78(2):242-245.

85. Dubey JP. Toxoplasmosis. J Am Vet Med Assoc. 1994;205(11): 1593-1598.

86. Jungi TW, Farhat K, Burgener IA, Werling D. Toll-like receptors in domestic animals. Cell Tissue Res. 2011;343(1):107-120.

87. Turin L, Riva F. Toll-like receptor family in domestic animal species. Crit Rev Immunol. 2008;28(6):513-538.

88. Mun HS, Aosai F, Chen M, et al. Pathogenicity of Toxoplasma gondii through B-2 cell-mediated downregulation of host defense responses. Microbiol Immunol. 2003;47(7):533-542.

89. Raetz M, Kibardin A, Sturge CR, et al. Cooperation of TLR12 and TLR11 in the IRF8-dependent IL-12 response to Toxoplasma gondii profilin. J Immunol. 2013;191(9):4818-4827.

90. Andrade WA, Souza Mdo C, Ramos-Martinez E, et al. Combined action of nucleic acid-sensing Toll-like receptors and TLR11/TLR12 heterodimers imparts resistance to Toxoplasma gondii in mice. Cell Host Microbe. 2013;13(1):42-53.

91. Wujcicka W, Wilczynski J, Nowakowska D. Do the placental barrier, parasite genotype and Toll-like receptor polymorphisms contribute to the course of primary infection with various Toxoplasma gondii genotypes in pregnant women? Eur J Clin Microbiol Infect Dis. November 30, 2013. [Epub ahead of print.] 
92. Pifer R, Yarovinsky F. Innate responses to Toxoplasma gondii in mice and humans. Trends Parasitol. 2011;27(9):388-393.

93. Schatz F, Kayisli UA, Vatandaslar E, et al. Toll-like receptor 4 expression in decidual cells and interstitial trophoblasts across human pregnancy. Am J Reprod Immunol. 2012;68(2):146-153.

94. Sturge CR, Benson A, Raetz M, et al. TLR-independent neutrophilderived IFN-gamma is important for host resistance to intracellular pathogens. Proc Natl Acad Sci U S A. 2013;110(26):10711-10716.

95. Miller CM, Boulter NR, Ikin RJ, Smith NC. The immunobiology of the innate response to Toxoplasma gondii. Int J Parasitol. 2009;39(1): 23-39.

96. Kang H, Remington JS, Suzuki Y. Decreased resistance of B celldeficient mice to infection with Toxoplasma gondii despite unimpaired expression of IFN-gamma, TNF-alpha, and inducible nitric oxide synthase. J Immunol. 2000;164(5):2629-2634.

97. Johnson LL, Sayles PC. Deficient humoral responses underlie susceptibility to Toxoplasma gondii in CD4-deficient mice. Infect Immun. 2002;70(1):185-191.

98. Sibley LD, Mordue DG, Su C, Robben PM, Howe DK. Genetic approaches to studying virulence and pathogenesis in Toxoplasma gondii. Philos Trans R Soc Lond B Biol Sci. 2002;357(1417):81-88.

99. Denkers EY, Butcher BA, Del Rio L, Bennouna S. Neutrophils, dendritic cells and Toxoplasma. Int J Parasitol. 2004;34(3):411-421.

100. Gazzinelli R, Xu Y, Hieny S, Cheever A, Sher A. Simultaneous depletion of $\mathrm{CD} 4+$ and $\mathrm{CD} 8+\mathrm{T}$ lymphocytes is required to reactivate chronic infection with Toxoplasma gondii. J Immunol. 1992;149(1): 175-180.

101. Johnson LL, Gibson GW, Sayles PC. CR3-dependent resistance to acute Toxoplasma gondii infection in mice. Infect Immun. 1996;64(6): 1998-2003.

102. Alexander J, Hunter CA. Immunoregulation during toxoplasmosis. Chem Immunol. 1998;70:81-102.

103. Jungi TW, Adler H, Adler B, Thony M, Krampe M, Peterhans E. Inducible nitric oxide synthase of macrophages. Present knowledge and evidence for species-specific regulation. Vet Immunol Immunopathol. 1996;54(1-4):323-330.

104. Hernandez-Mendoza L, Molinari JL, Garrido E, et al. The implantation of Taenia solium metacestodes in mice induces down-modulation of T cell proliferation and cytokine production. Parasitol Res. 2005;95(4): 256-265.

105. Kaneko Y, Takashima Y, Xuaun X, et al. Natural IgM antibodies in sera from various animals but not the cat kill Toxoplasma gondii by activating the classical complement pathway. Parasitology. 2004; 128 Pt 2:123-129.

106. Bailey M, Christoforidou Z, Lewis MC. The evolutionary basis for differences between the immune systems of man, mouse, pig and ruminants. Vet Immunol Immunopathol. 2013;152(1-2):13-19.

107. Zulpo DL, Headley SA, Biazzono L, et al. Oocyst shedding in cats vaccinated by the nasal and rectal routes with crude rhoptry proteins of Toxoplasma gondii. Exp Parasitol. 2012;131(2):223-230.

108. Machado AV, Caetano BC, Barbosa RP, et al. Prime and boost immunization with influenza and adenovirus encoding the Toxoplasma gondii surface antigen 2 (SAG2) induces strong protective immunity. Vaccine. 2010;28(18):3247-3256.

109. Bourguin I, Chardes T, Bout D. Oral immunization with Toxoplasma gondii antigens in association with cholera toxin induces enhanced protective and cell-mediated immunity in C57BL/6 mice. Infect Immun. 1993;61(5):2082-2088.

110. Crawford J, Lamb E, Wasmuth J, Grujic O, Grigg ME, Boulanger MJ. Structural and functional characterization of SporoSAG: a SAG2-related surface antigen from Toxoplasma gondii. J Biol Chem. 2010;285(16):12063-12070.

111. Burrells A, Bartley PM, Zimmer IA, et al. Evidence of the three main clonal Toxoplasma gondii lineages from wild mammalian carnivores in the UK. Parasitology. 2013;140(14):1768-1776.

112. Havelaar AH, Kemmeren JM, Kortbeek LM. Disease burden of congenital toxoplasmosis. Clin Infect Dis. 2007;44(11):1467-1474.
113. Falcon J, Freyre A. Toxoplasma gondii: prototype immunization of lambs against formation of muscle and brain cysts. Vet Parasitol. 2009;166(1-2):15-20.

114. Hiszczynska-Sawicka E, Li H, Xu JB, et al. Comparison of immune response in sheep immunized with DNA vaccine encoding Toxoplasma gondii GRA7 antigen in different adjuvant formulations. Exp Parasitol. 2010;124(4):365-372.

115. Hiszczynska-Sawicka E, Akhtar M, Kay GW, et al. The immune responses of sheep after DNA immunization with, Toxoplasma gondii MAG1 antigen-with and without co-expression of ovine interleukin 6. Vet Immunol Immunopathol. 2010;136(3-4):324-329.

116. Hiszczynska-Sawicka E, Li H, Xu JB, et al. Modulation of immune response to Toxoplasma gondii in sheep by immunization with a DNA vaccine encoding ROP1 antigen as a fusion protein with ovine CD154. Vet Parasitol. 2011;183(1-2):72-78.

117. Hiszczynska-Sawicka E, Li H, Boyu Xu J, et al. Induction of immune responses in sheep by vaccination with liposome-entrapped DNA complexes encoding Toxoplasma gondii MIC3 gene. Pol J Vet Sci. 2012;15(1):3-9.

118. Mevelec MN, Ducournau C, Bassuny Ismael A, et al. Mic1-3 knockout Toxoplasma gondii is a good candidate for a vaccine against $\mathrm{T}$. gondiiinduced abortion in sheep. Vet Res. 2010;41(4):49.

119. Dubey JP. Prevention of abortion and neonatal death due to toxoplasmosis by vaccination of goats with the nonpathogenic coccidium hammondia hammondi. Am J Vet Res. 1981;42(12):2155-2157.

120. Dubey JP. Protective immunity against clinical toxoplasmosis in dairy goats vaccinated with Hammondia hammondi and Hammondia heydorni. Am J Vet Res. 1981;42(12):2068-2070.

121. Chartier C, Mallereau MP. [Efficacite vaccinale de la souche S48 de Toxoplasma gondii vis-a-vis d'une infection experimentale chez le chevre]. Ann Méd Vét. 2001;145:202-209. French.

122. Dubey JP, Miller S, Desmonts G, Thulliez P, Anderson WR. Toxoplasma gondii-induced abortion in dairy goats. $\mathrm{J} \mathrm{Am} \mathrm{Vet} \mathrm{Med}$ Assoc. 1986;188(2):159-162.

123. Dubey JP. Persistence of encysted Toxoplasma gondii in caprine livers and public health significance of toxoplasmosis in goats. JAm Vet Med Assoc. 1980;177(12):1203-1207.

124. Chiari CA, Neves DP. Toxoplasmose humana adquirida através da ingestão de leite de cabra [Human toxoplasmosis acquired through ingestion of goat milk]. Memorias do Instituto Oswaldo Cruz. 1984;79(3):337-340. Portuguese.

125. Vitor RWA, Pinto JB, Chiari CA. Eliminação de Toxoplasma gondii através de urina, saliva e leite de caprinos experimentalmente infectados [Elimination of Toxoplasma gondii through urine, saliva and milk from experimentally infected goats]. Arq Brasil Med Vet e Zoot. 1991;42(2):147-154. Portuguese.

126. Dubey JP. Toxoplasmosis in pigs - the last 20 years. Vet Parasitol. 2009;164(2-4):89-103.

127. Li X, Wang Y, Yu F, Li T, Zhang D. An outbreak of lethal toxoplasmosis in pigs in the Gansu province of China. J Vet Diagn Invest. 2010;22(3):442-444.

128. Dubey JP. Long-term persistence of Toxoplasma gondii in tissues of pigs inoculated with $T$ gondii oocysts and effect of freezing on viability of tissue cysts in pork. Am J Vet Res. 1988;49(6):910-913.

129. Verhelst D, De Craeye S, Dorny P, et al. IFN-gamma expression and infectivity of Toxoplasma infected tissues are associated with an antibody response against GRA7 in experimentally infected pigs. Vet Parasitol. 2011;179(1-3):14-21.

130. da Cunha IA, Zulpo DL, Bogado AL, et al. Humoral and cellular immune responses in pigs immunized intranasally with crude rhoptry proteins of Toxoplasma gondii plus Quil-A. Vet Parasitol. 2012;186(3-4):216-221.

131. Wang Y, Zhang D, Wang G, Yin H, Wang M. Immunization with excreted-secreted antigens reduces tissue cyst formation in pigs. Parasitol Res. 2013;112(11):3835-3842.

132. Dubey JP, Lappin MR, Thulliez P. Long-term antibody responses of cats fed toxoplasma gondii tissue cysts. J Parasitol. 1995;81(6): $887-893$ 
133. Frenkel JK, Pfefferkorn ER, Smith DD, Fishback JL. Prospective vaccine prepared from a new mutant of Toxoplasma gondii for use in cats. Am J Vet Res. 1991;52(5):759-763.

134. Freyre A, Choromanski L, Fishback JL, Popiel I. Immunization of cats with tissue cysts, bradyzoites, and tachyzoites of the T-263 strain of Toxoplasma gondii. J Parasitol. 1993;79(5):716-719.

135. Mateus-Pinilla NE, Dubey JP, Choromanski L, Weigel RM. A field trial of the effectiveness of a feline Toxoplasma gondii vaccine in reducing T. gondii exposure for swine. J Parasitol. 1999;85(5):855-860.

136. Omata Y, Aihara Y, Kanda M, Saito A, Igarashi I, Suzuki N. Toxoplasma gondii: experimental infection in cats vaccinated with 60Co-irradiated tachyzoites. Vet Parasitol. 1996;65(3-4):173-183.

137. Mishima M, Xuan X, Yokoyama N, et al. Recombinant feline herpesvirus type 1 expressing Toxoplasma gondi ROP2 antigen inducible protective immunity in cats. Parasitol Res. 2002;88(2):144-149.

138. Williams DM, Grumet FC, Remington JS. Genetic control of murine resistance to Toxoplasma gondii. Infect Immun. 1978;19(2): 416-420.

139. Suzuki Y, Orellana MA, Wong SY, Conley FK, Remington JS. Susceptibility to chronic infection with Toxoplasma gondii does not correlate with susceptibility to acute infection in mice. Infect Immun. 1993;61(6):2284-2288.

140. Waterston RH, Lindblad-Toh K, Birney E, et al. Initial sequencing and comparative analysis of the mouse genome. Nature. 2002;420(6915): $520-562$.

141. Mestas J, Hughes CC. Of mice and not men: differences between mouse and human immunology. J Immunol. 2004;172(5):2731-2738.

142. Gibbons DL, Spencer J. Mouse and human intestinal immunity: same ballpark, different players; different rules, same score. Mucosal Immunol. 2011;4(2):148-157.

143. Garweg JG, de Kozak Y, Goldenberg B, Boehnke M. Anti-retinal autoantibodies in experimental ocular and systemic toxoplasmosis. Graefes Arch Clin Exp Ophthalmol. 2010;248(4):573-584.

144. Freyre A, Araujo FA, Fialho CG, Bigatti LE, Falcon JD. Protection in a hamster model of congenital toxoplasmosis. Vet Parasitol. 2012;183(3-4):359-363.

145. Gormley PD, Pavesio CE, Minnasian D, Lightman S. Effects of drug therapy on Toxoplasma cysts in an animal model of acute and chronic disease. Invest Ophthalmol Vis Sci. 1998;39(7):1171-1175.

146. Esteban-Redondo I, Innes EA. Detection of Toxoplasma gondii in tissues of sheep orally challenged with different doses of oocysts. Int J Parasitol. 1998;28(9):1459-1466.

147. Benavides J, Maley S, Pang Y, et al. Development of lesions and tissue distribution of parasite in lambs orally infected with sporulated oocysts of Toxoplasma gondii. Vet Parasitol. 2011;179(1-3): 209-215.

148. Garcia JL, Gennari SM, Navarro IT, et al. Partial protection against tissue cysts formation in pigs vaccinated with crude rhoptry proteins of Toxoplasma gondii. Vet Parasitol. 2005;129(3-4):209-217.

149. Bugni FM, Da Cunha IA, De Araujo MA, et al. [Action of beta-glucan in pigs experimentally infected with Toxoplasma gondii tachyzoites]. Rev Bras Parasitol Vet. 2008;17 Suppl 1:249-259. Portuguese.

150. Havelaar AH, van Rosse F, Bucura C, et al. Prioritizing emerging zoonoses in the Netherlands. PLoS One. 2010;5(11):e13965.

151. Moeller RB Jr. Causes of caprine abortion: diagnostic assessment of 211 cases (1991-1998). J Vet Diagn Invest. 2001;13(3):265-270.

152. Silva Filho MdF, Erzinger E, Cunha IAL, et al. Toxoplasma gondii: abortion outbreak in a goatherd from Southern Brazil. Semina: Ciências Agrárias, Londrina. 2008;29(4):887-894.

153. Lu F, Huang S, Kasper LH. The temperature-sensitive mutants of Toxoplasma gondii and ocular toxoplasmosis. Vaccine. 2009;27(4): 573-580.

154. Martinez-Gomez F, Garcia-Gonzalez LF, Mondragon-Flores R, Bautista-Garfias CR. Protection against Toxoplasma gondii brain cyst formation in mice immunized with Toxoplasma gondii cytoskeleton proteins and Lactobacillus casei as adjuvant. Vet Parasitol. 2009; 160(3-4):311-315.
155. Beauvillain C, Juste MO, Dion S, Pierre J, Dimier-Poisson I. Exosomes are an effective vaccine against congenital toxoplasmosis in mice. Vaccine. 2009;27(11):1750-1757.

156. Wang H, He S, Yao Y, et al. Toxoplasma gondii: protective effect of an intranasal SAG1 and MIC4 DNA vaccine in mice. Exp Parasitol. 2009;122(3):226-232.

157. Moire N, Dion S, Lebrun M, Dubremetz JF, Dimier-Poisson I. Mic1-3KO tachyzoite a live attenuated vaccine candidate against toxoplasmosis derived from a type I strain shows features of type II strain. Exp Parasitol. 2009;123(2):111-117.

158. Dziadek B, Gatkowska J, Brzostek A, Dziadek J, Dzitko K, Dlugonska H. Toxoplasma gondii: the immunogenic and protective efficacy of recombinant ROP2 and ROP4 rhoptry proteins in murine experimental toxoplasmosis. Exp Parasitol. 2009;123(1):81-89.

159. Jordan KA, Wilson EH, Tait ED, et al. Kinetics and phenotype of vaccine-induced CD8+ T cell responses to Toxoplasma gondii. Infect Immun. 2009;77(9):3894-3901.

160. Qu D, Yu H, Wang S, Cai W, Du A. Induction of protective immunity by multiantigenic DNA vaccine delivered in attenuated Salmonella typhimurium against Toxoplasma gondii infection in mice. Vet Parasitol. 2009;166(3-4):220-227.

161. Gigley JP, Fox BA, Bzik DJ. Long-term immunity to lethal acute or chronic type II Toxoplasma gondii infection is effectively induced in genetically susceptible C57BL/6 mice by immunization with an attenuated type I vaccine strain. Infect Immun. 2009;77(12):5380-5388.

162. Fox BA, Bzik DJ. Avirulent uracil auxotrophs based on disruption of orotidine-5'-monophosphate decarboxylase elicit protective immunity to Toxoplasma gondii. Infect Immun. 2010;78(9):3744-3752.

163. Laguia-Becher M, Martin V, Kraemer M, et al. Effect of codon optimization and subcellular targeting on Toxoplasma gondii antigen SAG1 expression in tobacco leaves to use in subcutaneous and oral immunization in mice. BMC Biotechnol. 2010;10:52.

164. Dziadek B, Gatkowska J, Brzostek A, et al. Evaluation of three recombinant multi-antigenic vaccines composed of surface and secretory antigens of Toxoplasma gondii in murine models of experimental toxoplasmosis. Vaccine. 2011;29(4):821-830.

165. Yuan ZG, Zhang XX, He XH, et al. Protective immunity induced by Toxoplasma gondii rhoptry protein 16 against toxoplasmosis in mice. Clin Vaccine Immunol. 2011;18(1):119-124.

166. Makino M, Uemura N, Moroda M, et al. Innate immunity in DNA vaccine with Toxoplasma gondii-heat shock protein 70 gene that induces DC activation and Th1 polarization. Vaccine. 2011;29(10): 1899-1905.

167. Mendes EA, Caetano BC, Penido ML, Bruna-Romero O, Gazzinelli RT. MyD88-dependent protective immunity elicited by adenovirus 5 expressing the surface antigen 1 from Toxoplasma gondii is mediated by CD8(+) T lymphocytes. Vaccine. 2011;29(27):4476-4484.

168. Sanchez VR, Pitkowski MN, Fernandez Cuppari AV, et al. Combination of CpG-oligodeoxynucleotides with recombinant ROP2 or GRA4 proteins induces protective immunity against Toxoplasma gondii infection. Exp Parasitol. 2011;128(4):448-453.

169. Rashid I, Hedhli D, Moire N, et al. Immunological responses induced by a DNA vaccine expressing RON4 and by immunogenic recombinant protein RON4 failed to protect mice against chronic toxoplasmosis. Vaccine. 2011;29(48):8838-8846.

170. Yuan ZG, Zhang XX, Lin RQ, et al. Protective effect against toxoplasmosis in mice induced by DNA immunization with gene encoding Toxoplasma gondii ROP18. Vaccine. 2011;29(38):6614-6619.

171. Wang PY, Yuan ZG, Petersen E, et al. Protective efficacy of a Toxoplasma gondii rhoptry protein 13 plasmid DNA vaccine in mice. Clin Vaccine Immunol. 2012;19(12):1916-1920.

172. Cui X, Lei T, Yang D, Hao P, Li B, Liu Q. Toxoplasma gondii immune mapped protein-1 (TgIMP1) is a novel vaccine candidate against toxoplasmosis. Vaccine. 2012;30(13):2282-2287.

173. Li J, Han Q, Gong P, et al. Toxoplasma gondii rhomboid protein 1 (TgROM1) is a potential vaccine candidate against toxoplasmosis. Vet Parasitol. 2012;184(2-4):154-160. 
174. Chuang SC, Ko JC, Chen CP, Du JT, Yang CD. Encapsulation of chimeric protein $\mathrm{rSAG} 1 / 2$ into poly(lactide-co-glycolide) microparticles induces long-term protective immunity against Toxoplasma gondii in mice. Exp Parasitol. 2013;134(4):430-437.

175. Yuan ZG, Ren D, Zhou DH, et al. Evaluation of protective effect of pVAX-TgMIC13 plasmid against acute and chronic Toxoplasma gondii infection in a murine model. Vaccine. 2013;31(31):3135-3139.
176. Zhao Y, Huang B, Huang S, et al. Evaluation of the adjuvant effect of pidotimod on the immune protection induced by UV-attenuated Toxoplasma gondii in mouse models. Parasitol Res. 2013;112(9): $3151-3160$.

\section{Publish your work in this journal}

Vaccine: Development and Therapy is an international, peer-reviewed, open access journal that spans the spectrum of vaccine design and development through to clinical applications. The journal is characterized by the rapid reporting of application notes, reviews, original research and clinical studies in all therapeutic areas. Clinical outcomes, patient safety,
Dovepress

and programs for the development and effective, safe, and sustained use of vaccines will be a feature of the journal. The manuscript management system is completely online and includes a very quick and fair peer-review system. Visit http://www.dovepress.com/testimonials.php to read real quotes from published authors.

Submit your manuscript here: http://www.dovepress.com/vaccine-development-and-therapy-journal 